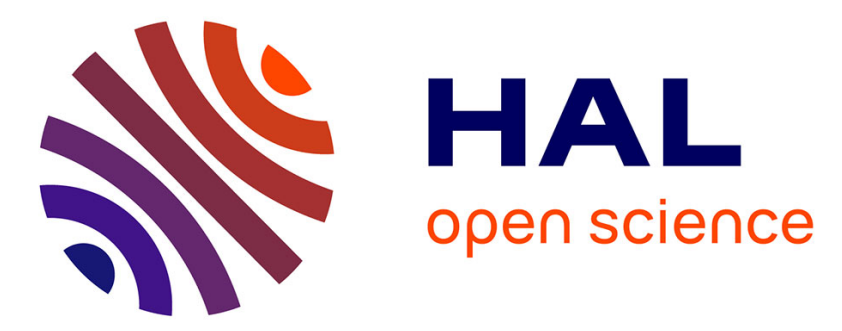

\title{
Agriculture and greenhouse gases, a common tragedy. A review
}

\author{
Ilan Stavi, Rattan Lal
}

\section{To cite this version:}

Ilan Stavi, Rattan Lal. Agriculture and greenhouse gases, a common tragedy. A review. Agronomy for Sustainable Development, 2013, 33 (2), pp.275-289. 10.1007/s13593-012-0110-0 . hal-01201354

\section{HAL Id: hal-01201354 \\ https://hal.science/hal-01201354}

Submitted on 17 Sep 2015

HAL is a multi-disciplinary open access archive for the deposit and dissemination of scientific research documents, whether they are published or not. The documents may come from teaching and research institutions in France or abroad, or from public or private research centers.
L'archive ouverte pluridisciplinaire HAL, est destinée au dépôt et à la diffusion de documents scientifiques de niveau recherche, publiés ou non, émanant des établissements d'enseignement et de recherche français ou étrangers, des laboratoires publics ou privés. 


\title{
Agriculture and greenhouse gases, a common tragedy. A review
}

\author{
Ilan Stavi • Rattan Lal
}

Accepted: 31 July 2012 /Published online: 5 September 2012

(C) INRA and Springer-Verlag, France 2012

\begin{abstract}
Increased atmospheric concentrations of greenhouse gases has led to global warming and associated climatic changes. The problem has been aggravated by the perception that the atmosphere is an infinite and toll-free resource. The well-known concept proposed by Garrett Hardin - "The Tragedy of the Commons"-highlights the misuse of common resources, which ultimately lead to their depletion. This article emphasizes the relevance of the same concept to the current climatic changes and highlights the impact of agriculture on the environment. The specific focus is on field crop production and livestock husbandry that have resulted in deteriorating environmental services and increased greenhouse gas emissions. Meanwhile, the total amount of energy consumed by these sectors is enormous, encompassing 11 exajoules (EJ) annually. In addition, the article highlights possible impacts of climate change on agricultural productivity. Considering the foreseen growth of the global human population, it is expected that additional pressures will aggravate natural environments. Adoption of recommended management practices is crucial to reverse the environmental footprint of agriculture and lessen its impact on climate change. Regarding croplands, these practices can include reduced tillage systems, crop residue management, improved management of nutrients and pests, cover cropping, agroforestry, biochar application as soil amendment, and utilization of precision agriculture technologies. In the livestock sector, recommended management practices include changes in animals' diet and appropriate management of manure. Adoption of these practices is also
\end{abstract}

I. Stavi $(\bowtie)$

Dead Sea \& Arava Science Center,

Ketura 88840, Israel

e-mail: istavi@yahoo.com

R. Lal

Carbon Management and Sequestration Center, Ohio State

University,

Columbus, OH 43210, USA expected to decrease the on-farm and off-farm energy use. To encourage the adoption of these practices, authorities should provide the farmers with incentives, such as payments for improving environmental services. Also, international regulations must be enforced to instigate a notable shift in human diets with the goal of reducing the environmental impact of food production. Judicious implementation of related policies would be crucial for promoting the required links between agricultural production and environmental sustainability.

Keywords Biofuel cropping · Climate change · Energy use · Environmental services $\cdot$ Fertilizer use $\cdot$ Livestock raising · Tillage operations

$\begin{array}{ll}\text { Abbreviations } \\ \text { ASF } & \text { Animal source foods } \\ \text { BMPs } & \text { Best management practices } \\ \mathrm{C} & \text { Carbon } \\ \mathrm{CE} & \text { Carbon equivalent } \\ \mathrm{CH}_{4} & \text { Methane } \\ \mathrm{CO}_{2} & \text { Carbon dioxide } \\ \mathrm{CO}_{2} \text {-e } & \text { Carbon dioxide equivalent } \\ \mathrm{LME} & \text { Liquid milk equivalent } \\ \mathrm{N}_{2} \mathrm{O} & \text { Nitrous oxide } \\ \mathrm{N} & \text { Nitrogen } \\ \mathrm{NT} & \text { No-till } \\ \text { SOC } & \text { Soil organic carbon }\end{array}$

Contents

1. Introduction. . . . . . . . . . . . . . . 2

2. Cropland intensification and climate change. .....3

3. The livestock sector. . . . . . . . . . . . . . . . . . . .6

4. Climate change impact on agricultural productivity. . .8

5. Management, policy, and regulations. ..........11

6. Conclusions. . . . . . . . . . . . . . . . . . . . 16 


\section{Introduction}

Food production entails high environmental costs because of large emissions of greenhouse gases from soil, plant, and livestock (FAO 2006), as well as substantial energy consumption in growing, transporting, processing, and refrigerating the food products (Fiala 2009). Some inappropriate agricultural activities also impose other adverse environmental impacts such as contamination and eutrophication of terrestrial and aqueous habitats, loss of biodiversity, and accelerated soil erosion (Lal 2007).

The concept "The Tragedy of the Commons" was initially proposed by Hardin (1968), to describe the misuse and overexploitation of common or public resources. Hardin used this concept specifically to describe the overexploitation of public rangelands. He hypothesized that every herdsman is rationally pushed to maximize gains by adding animals to his herd. At a certain stage, the carrying capacity of the rangeland ecosystem is reached, and every additional animal leads to overstocking. Yet, the expected revenue for any herdsman from the addition of animals to his herd is greater than the expected loss of revenue due to the decreased quantity and quality of pasture per animal. This is because the declined pasture is shared with other herds that use the same common land. Under these conditions, each herdsman is locked into a system that compels him/her to increase the herd without limit, leading to a gradual degradation of the rangeland's resources. Hardin added that this concept is also relevant to pollution of common natural resources, such as the discharge of pollutants into rivers, other water bodies, or land areas because each producer of these pollutants perceives this practice as the cheapest way of their disposal.

Similarly to the misuse of land areas and water bodies, which stems from their common nature, the increase in atmospheric concentrations of greenhouse gases also derives from the perception of the atmosphere as a common property (Lal 2007). Until the late 1990s, carbon dioxide $\left(\mathrm{CO}_{2}\right)$ produced by burning of fossil or woody fuels was considered valueless, and the cheapest mode of its disposal was simply to let it be emitted into the atmosphere. In the same manner, the oxidation of soil organic carbon (SOC), caused by the conversion of natural ecosystems to cultivated lands, was not restricted and was considered as a legitimate environmental cost of agricultural production. As long as the emission of greenhouse gases is free of any costs, the economic rationale of the relevant sectors is to increase industrial or agricultural production with the associated increased emissions of $\mathrm{CO}_{2}$. Likewise, emissions of the potent greenhouse gas methane $\left(\mathrm{CH}_{4}\right)$, derived from ruminant husbandry and cultivation of rice (Oryza sativa L.) paddies, as well of nitrous oxide $\left(\mathrm{N}_{2} \mathrm{O}\right)$ from a range of industrial processes and fertilizers used in croplands, are expected to increase (Stavi and Lal 2012). The global warming potential of $\mathrm{CH}_{4}$ and $\mathrm{N}_{2} \mathrm{O}$ over 100 years, being, respectively, 21 and 310 times larger than that of $\mathrm{CO}_{2}$ (IPCC 2007), further highlights the environmental impact of agriculture on global warming. Similar to the unidirectional shift of common rangelands' resources to extreme degradation (Hardin 1968), emissions of greenhouse gases associated with agricultural activities are expected to continue to increase, exacerbating the risk of climatic change (FAO 2006).

Unless new technologies and prudent changes in lifestyles are adopted globally over the coming decades, the projected increases in global energy and food consumption will greatly elevate atmospheric abundance of greenhouse gases from fossil fuel combustion, land clearing, cement manufacturing, etc. and will cause biodiversity loss from habitat destruction and climate change (Tilman et al. 2009). Yet, as is already known for other environmental-related issues, desired changes in behavior and attitudes of individuals cannot rely solely on their own will and therefore should be encouraged through regulations and policy incentives (Meyerson 1998). Also, the projected increase in affluence of several emerging economies (Delgado 2003) must lead to adoption of advanced procedures and technologies aimed at increasing efficiency of food production. In accord with judicious economic investments within households, cooperatives, and commercial companies, redistribution of resources must be undertaken on national and international levels, aimed at encouraging the adoption of sustainable practices and reduction of emissions from agricultural activities.

\section{Cropland intensification and climate change}

Land converted to agriculture to meet global food demand comes from forests, grasslands, and other natural habitats (Tilman et al. 2001). The expansion of cultivated lands and the intensification of agriculture have led to the release of enormous amounts of greenhouse gases. One of the major contributors of $\mathrm{CO}_{2}$ emissions from agricultural lands is soil tillage (Fig. 1), leading to oxidation of SOC. Of the total SOC, the particulate organic C (POC 50 to $2,000 \mu \mathrm{m}$ ) is highly labile and most vulnerable to decomposition. Also, tillage results in breakdown of macro-aggregates, accelerating oxidation rates of the formerly protected SOC (Six et al. 2000). The decreased SOC pool results in the reduction of the physical and chemical quality of the soil, decreasing its fertility and productive capacity (Stavi et al. 2011). Most agricultural soils have lost between 30 and $75 \%$ of their original SOC pool, or about $30-40 \mathrm{Mg} \mathrm{C} \mathrm{ha}^{-1}$ (Lal et al. 2007). Tillage may also increase emissions of $\mathrm{N}_{2} \mathrm{O}$ from soil. The rate of $\mathrm{N}_{2} \mathrm{O}$ emissions is related to the soil's 


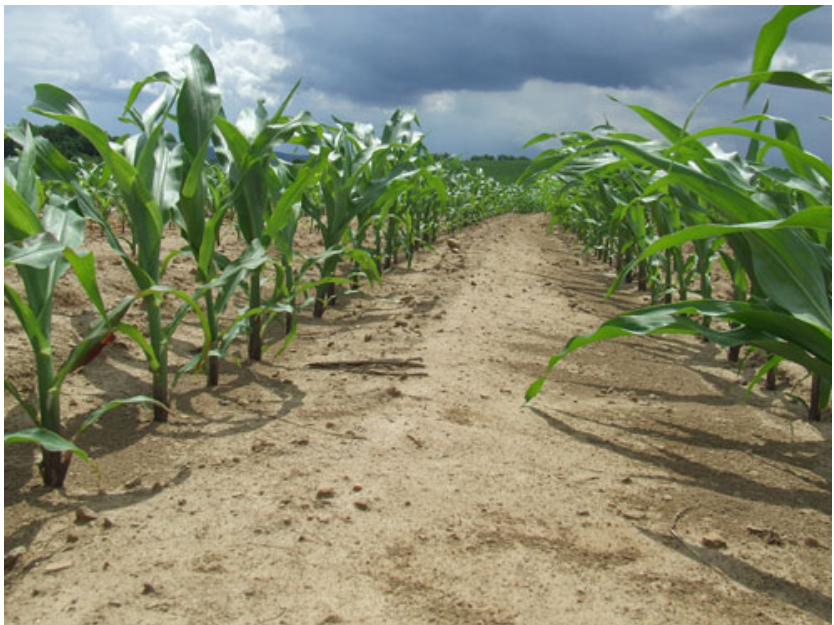

Fig. 1 Continuous corn cropping under intensive tillage system, eastern Ohio, Midwest USA. Note the mechanical crust covering the soil surface. Photographed by I. Stavi

moisture, temperature, and nitrate $\left(\mathrm{NO}_{3}\right)$ concentration (Perdomo et al. 2009). Manuring is another major source of $\mathrm{CO}_{2}$ emissions, caused by the enhanced microbial activity (Matsumoto et al. 2008). Decomposition rates of manure could be decreased if retained on the soil surface. However, this practice may enhance its susceptibility to water erosion, leading to undesired nutrient enrichment in downstream water bodies (Franzluebbers et al. 2007). Yet, this practice may be valuable for flat terrains, where rainstorms do not result in an excessive water runoff. Application of nitrogen (N)-based fertilizers is a key determinant of $\mathrm{N}_{2} \mathrm{O}$ emissions, as excess $\mathrm{N}$ not absorbed by the plants is subject to gaseous emissions (Smith et al. 2008). These emissions are attributed to the processes of nitrification: the aerobic microbial oxidation of ammonium $\left(\mathrm{NH}_{4}\right)$ to nitrate; as well as to denitrification: the anaerobic microbial reduction of nitrate to dinitrogen $\left(\mathrm{N}_{2}\right)$. In addition, excess fertilizers are susceptible to runoff or to deep leaching, resulting in contamination and eutrophication of above- or below-ground water sources (DeAngelo et al. 2006) and anoxia of coastal ecosystems (Committee on Environment and Natural Resources 2010).

Besides direct effects of agricultural intensification on greenhouse gas emissions, it also indirectly affects the $\mathrm{C}$ cycle by altering soil's erodibility. Excessive tillage reduces stability of soil structure, decreases infiltrability of water, and lessens hydraulic conductivity of the soil (MoebiusClune et al. 2008). At the same time, incorporation of crop residues into the soil increases raindrop splash impact and enhances aggregate slaking and dispersion (Lal 2003). These processes result in the increased erodibility of the soil and also affect SOC dynamics. Fate of SOC transported by erosional processes is debatable and probably affected by site-specific conditions. While some studies have reported long-term burying of eroded SOC in terrestrial depositional sites or aquatic bodies (Van Oost et al. 2007; Harden et al. 2008), others have indicated that erosional processes increase breakdown of aggregates and oxidation of SOC (Stavi and Lal 2011a, b). One way or another, the decreased SOC pool in the surface layer reduces microbial activity and nutrient turnover, weakens formation and stability of soil structure, and lowers availability of water for vegetation, thereby lessening agronomic productivity and crop yields (Lal 2003).

Traditional paddy rice production is one of the largest sources of global greenhouse gases, especially that of $\mathrm{N}_{2} \mathrm{O}$ and $\mathrm{CH}_{4}$ (DeAngelo et al. 2006; Fig. 2). In flooded rice paddies, $\mathrm{N}_{2} \mathrm{O}$ and $\mathrm{CH}_{4}$ are produced through numerous microbial processes. For example, $\mathrm{N}_{2} \mathrm{O}$ is generated from denitrification of nitrate derived from $\mathrm{N}$ fertilizers. This process also results in enormous $\mathrm{N}$ losses and low $\mathrm{N}$ fertilizer use efficiency (Kögel-Knabner et al. 2010). The rate of $\mathrm{N}_{2} \mathrm{O}$ emission increases with increase in temperatures (Smith et al. 2003). Production of $\mathrm{CH}_{4}$ can occur in the rhizosphere, driven by root exudates, as well as during litter degradation in the bulk soil (Kögel-Knabner et al. 2010). Emission rates of $\mathrm{N}_{2} \mathrm{O}$ and $\mathrm{CH}_{4}$ from paddies depend on soil type, climate, water management regime, fertilizer use, and rice cultivar (DeAngelo et al. 2006).

Besides the impact of land use and management, a major agricultural component that affects global warming is the energy use in croplands including agrochemicals and tillage operations which consume large amounts of fossil fuel (Lal 2004; Huggins and Reganold 2008). Nelson et al. (2009) examined the energy utilization and greenhouse gas emissions from the most widespread crops in the USA, including wheat (Triticum aestivum L.), barley (Hordeum vulgare L.), corn (Zea mays L.), soybean (Glycine max L.), cotton (Gossypium herbaceum L.), hay, oat (Avena sativa L.), sorghum (Sorghum bicolor L.), and rice. They estimated that overall on-farm energy use and $\mathrm{CO}_{2}$ emissions range from 1.6 to $7.9 \mathrm{GJ} \mathrm{ha}^{-1}$ year $^{-1}$ and from 23 to $176 \mathrm{~kg} \mathrm{C} \mathrm{ha}^{-1}$ year $^{-1}$,

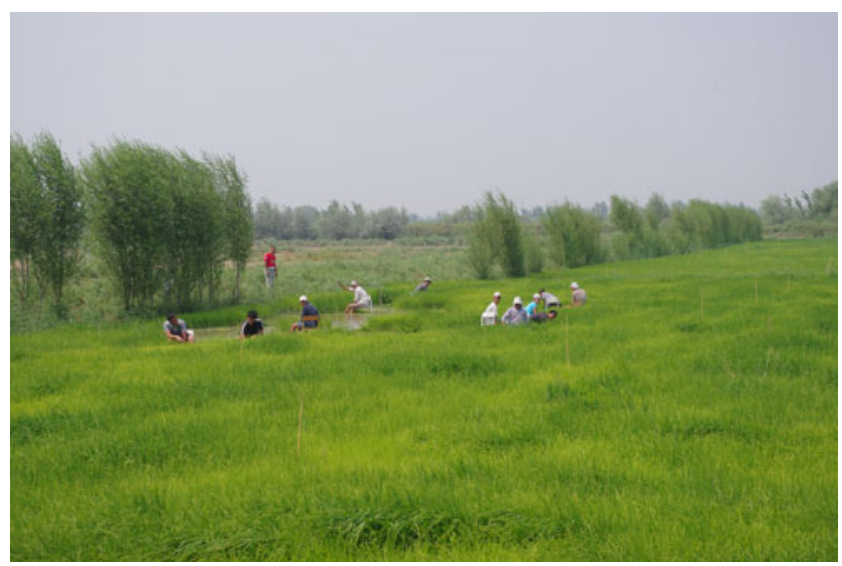

Fig. 2 Paddy rice planting, western Uzbekistan. Photographed by I. Stavi 
respectively. In addition, agricultural production accounts for off-farm emissions related to the manufacture and transport of fertilizers, herbicides, and pesticides. Nelson and colleagues calculated that in the USA's croplands, total (the sum of on-farm and off-farm) energy use and $\mathrm{CO}_{2}$ emissions range from 5.5 to $20.5 \mathrm{GJ} \mathrm{ha}^{-1}$ year $^{-1}$ and from 91 to $365 \mathrm{~kg} \mathrm{C} \mathrm{ha}^{-1}$ year $^{-1}$, respectively. Also, irrigation of croplands is associated with both off-farm and on-farm emissions. Lal (2004) calculated that C emissions related with installation of a range of irrigation systems vary between $\sim 10$ and $\sim 120 \mathrm{~kg} \mathrm{C}$ equivalent (CE) ha ${ }^{-1}$ year $^{-1}$. Several studies that examined the use of energy and fuel and the emissions of greenhouse gases in relation to cropland systems are presented in Table 1. These studies reveal wide ranges of energy and fuel consumption rates and greenhouse gas emissions involved with croplands activities, including tillage operations, nutrient management, and pest and weed control. Of these studies, especially noteworthy is that by Hoeppner et al. (2006), who revealed the large share of energy investments in fertilizers and pesticides, encompassing between 43 and $51 \%$ and between 7 and $10 \%$, respectively, of total (off-farm and onfarm) energy use in croplands systems. Yet, in regard with onfarm fuel use, it is acknowledged that advances in agricultural technologies along the temporal axis improve fuel efficiency and, thereby, considerably reducing emissions of greenhouse gases from farming activities (Schneider and Smith 2009). Nevertheless, the yearly 11 EJ of the world's energy consumption in agriculture is expected to increase between 0.8 and $2.9 \%$ annually between the years of 2000 and 2030 (Price et al. 2006).

Globally, about 1.6 billion ha of land is currently used for crop production, of which almost 1 billion ha is in developing countries. During the last 30 years, the world's cropland area has expanded by $\sim 5$ million ha annually, with Latin America alone accounting for $35 \%$ of this increase. The potential for arable land expansion exists predominately in Latin America and Africa. At the same time, there is relatively little scope for arable land expansion in Asia, which is home to $\sim 60 \%$ of the world's population (OFID 2009). On a global scale, agricultural lands account for about $25 \%$ of the $\mathrm{CO}_{2}, 50 \%$ of the $\mathrm{CH}_{4}$, and $70 \%$ of the $\mathrm{N}_{2} \mathrm{O}$ anthropogenic emissions (Hutchinson et al. 2007). Together with ozone-depleting chlorofluorocarbons, these types of gases account for approximately $96 \%$ of the increase in radiative forcing due to long-lived greenhouse gases that has occurred since 1750 . From 1990 to 2009, radiative forcing by all gases increased by $27.5 \%$, with $\mathrm{CO}_{2}$ accounting for nearly $85 \%$ of this increase (WMO 2010). In addition to global warming, the expansion of agriculture is a major driver of global environmental change. By 2050, global cropland would increase by a net of $3.5 \times 10^{8}$ ha. This would be accompanied by $2.4-$ to 2.7 -fold increases in pesticide and fertilizer use and would lead to contamination of habitats and eutrophication of water sources. An additional 5.4× $10^{8}$ ha would be converted to pasturelands. This would cause unprecedented simplification of ecosystems, loss of environmental services, extinction of species, and harm to human health (Tilman et al. 2001).

\section{The livestock sector}

Livestock husbandry is a major anthropogenic contributor of climate change. Emissions of greenhouse gases from grazing lands occur in a variety of ways. First, conversion of natural ecosystems to grazing lands decreases the system's C pools in plant biomass (Kauffman et al. 2003; Fig. 3) and soil profile (de Jong et al. 2010). Second, utilization of paddocks results in emissions of greenhouse gases. Overall, it could be stated that higher stocking rates decrease $\mathrm{C}$ pools in vegetation and soil and increase emissions of $\mathrm{CH}_{4}$ from enteric fermentation in ruminants. Utilizing $\mathrm{N}$-fertilizer for increasing net primary productivity, despite increasing the paddock-C pool, also augments emissions of $\mathrm{N}_{2} \mathrm{O}$ from soil (Allard et al. 2007). Also, raising livestock requires a large amount of supplemental feed per unit of body weight. Production of the feed itself results in the emission of greenhouse gases related to its growing, such as those from agricultural machinery work and fertilizer use. In addition, farms for raising animals produce numerous wastes that lead to greenhouse gas emissions (Fiala 2009). The current production systems for meat products account for between 15 and $24 \%$ of the global anthropogenic emissions of greenhouse gases (Fiala 2008), a share larger than global emissions from waste disposal (3\%), manufacturing (7\%), residential (10\%), and transportation (14\%) (Fiala 2009).

Feed production for livestock has been based mainly on grains and, to a smaller extent, on oilseeds and hay. The global feed use of cereals is over $650 \mathrm{Tg}$, or $35 \%$ of the world's total cereal use (FAO 2006), and the worldwide production of cereals for feed will be expanded by an additional $295 \mathrm{Tg} \mathrm{year}^{-1}$ by 2020 , compared to the 1996/ 1998 annual average. Developing countries accounted for $36 \%$ of global cereal feed use in 1996/1998 but are projected to account for $46 \%$ in 2020 . Yet, on a human per capita basis, averaged cereal feed use in 2020 in developed countries is projected to be $375 \mathrm{~kg}$, compared to only $72 \mathrm{~kg}$ in developing countries (Delgado 2003).

Global consumption of meat has been increasing tremendously and is likely to continue to do so into the future (Fiala 2008). However, in many developing countries, where the need to increase protein consumption is the greatest, meat consumption has been far below the standard requirements. There are 26 developing countries with an 


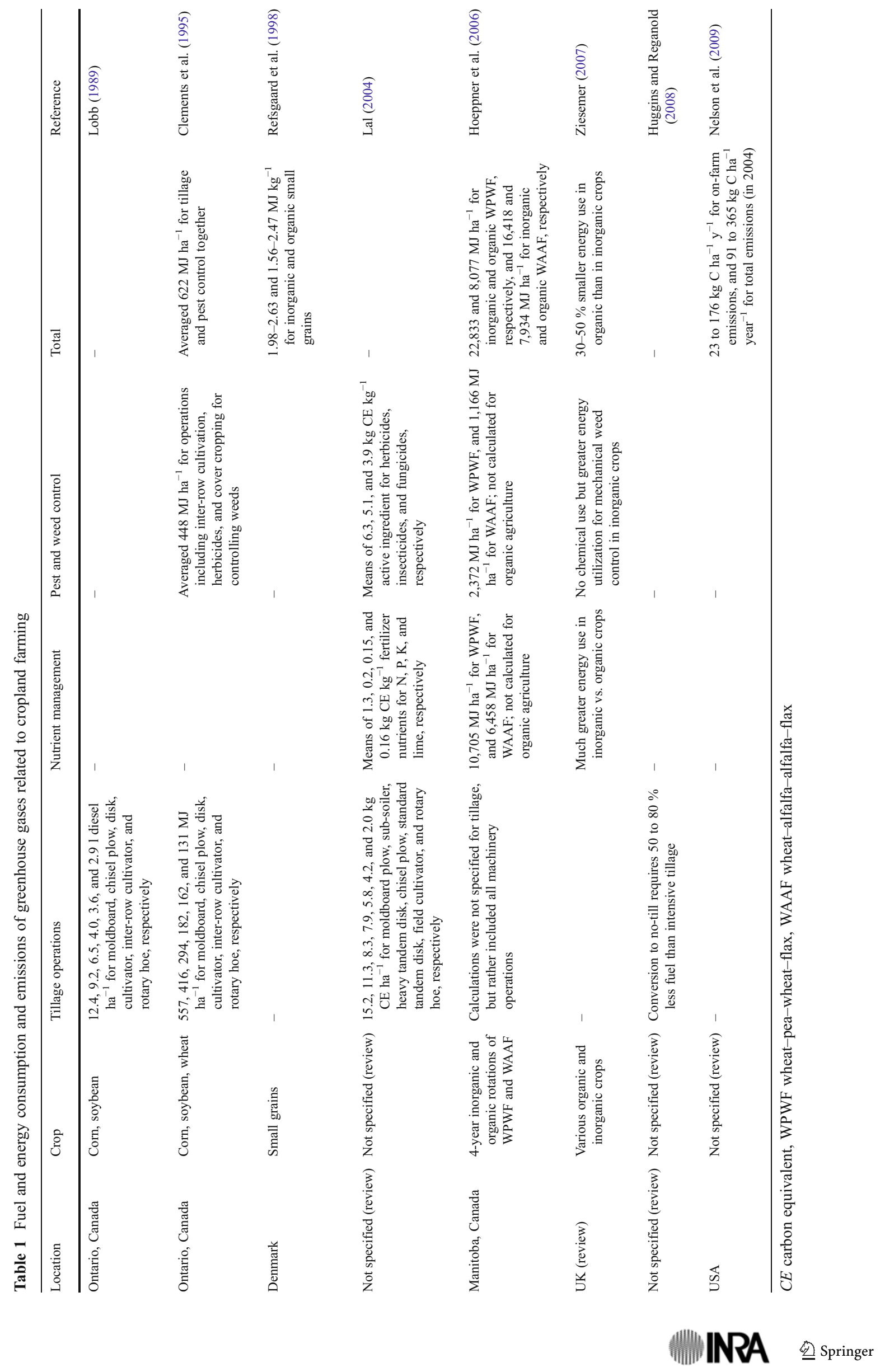




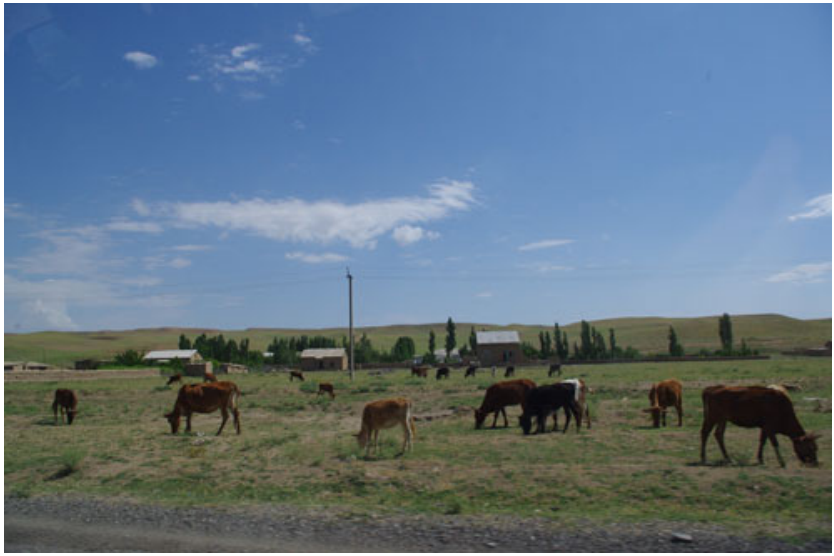

Fig. 3 Extensive livestock grazing, central Uzbekistan. Note the sparse vegetation cover. Photographed by I. Stavi

average annual consumption of meat under $10 \mathrm{~kg}$ per capita and 30 additional developing countries with an average of between 10 and $20 \mathrm{~kg}$, as compared to an average of $90 \mathrm{~kg}$ in industrial countries. Yet, the annual growth rate in meat consumption has grown at $6 \%$ in the developing world (Delgado 2003). This is because per capita consumption has been growing continuously in some emerging economies, such as China and Brazil (FAO 2006), leading to a much faster total growth rate in the developing than in the developed world (Delgado 2003). Therefore, average meat consumption in developing countries is projected to grow by $106 \mathrm{Tg}$ between the late 1990s and 2020, whereas the corresponding figure for developed countries is only $19 \mathrm{Tg}$ (Delgado 2003). Yet, in 2050, average yearly per capita meat consumption is projected at $103 \mathrm{~kg}$ in developed countries and at only $44 \mathrm{~kg}$ in developing countries (Garnett 2009).

Global milk consumption has also increased tremendously during the last decades. Since the 1980s, consumption has increased at an annual rate of $4 \%$ in the developing world. Yet, during the late 1990s, average per capita annual milk consumption in developing countries was $44 \mathrm{~kg}$, which was only about one fifth of that in developed countries. Projections for global milk consumptions vary between no or small change (FAO 2006) and a sharp increase, mainly due to the greater demands in some developing countries (Delgado 2003). Projection of averaged increased milk consumption between the late 1990s and 2020 in the developing world is $177 \mathrm{Tg}$ of liquid milk equivalent (LME), compared to $32 \mathrm{Tg}$ LME in the developed world (Delgado 2003). Yet, average yearly per capita milk consumption in 2050 is projected at $227 \mathrm{~kg}$ in the developed world, compared to only $78 \mathrm{~kg}$ in the developing world (Garnett 2009).

Intensive livestock operations on an industrial scale, mostly in developed countries but increasingly also in developing countries (Fig. 4), are a major source of environmental concerns (FAO 2006). These operations, despite

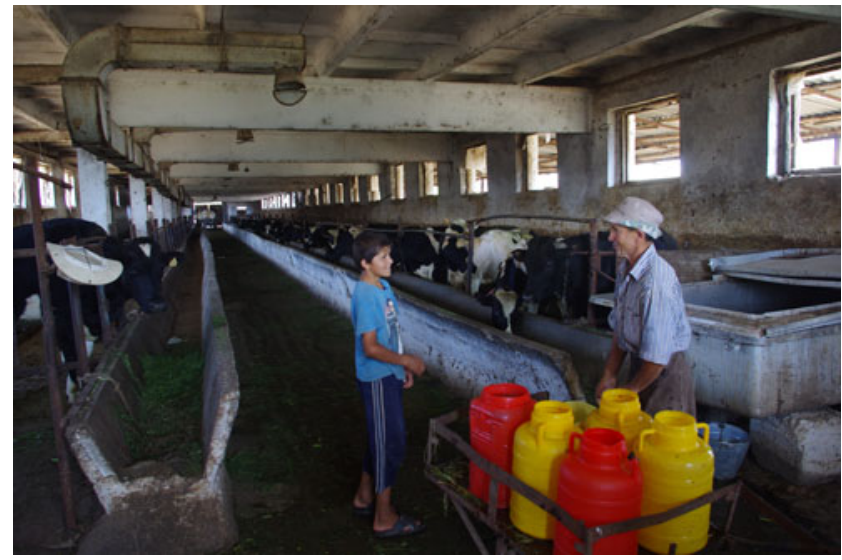

Fig. 4 Bull fattening in an intensive livestock operation system, western Tajikistan. Photographed by I. Stavi

revealing higher economic viability and emitting fewer greenhouse gases than non-concentrated systems, have a severe impact on global warming. Under these systems, beef production emits the greatest amount of greenhouse gases, with $14.8 \mathrm{~kg} \mathrm{CO}_{2}$ equivalent $\left(\mathrm{CO}_{2}-\mathrm{e}\right) \mathrm{kg}^{-1}$. This is due in part to the $\mathrm{CH}_{4}$ emissions from cows. Pork has a much lower impact, with $3.8 \mathrm{~kg} \mathrm{CO}_{2}-\mathrm{e} \mathrm{kg}^{-1}$, and chicken is the least, with $1.1 \mathrm{~kg} \mathrm{CO}_{2}-\mathrm{e} \mathrm{kg}^{-1}$. Among the other factors, the amount of energy input for production of unit products is of special importance, with unit weight of pork products using $1 / 3$ as much fossil fuel as beef and chicken using about $1 / 8$ of beef (Fiala 2008). Fiala projected that global emissions of greenhouse gases from the production of chicken, pork, and beef will reach, respectively, 121,509 , and $1,077 \mathrm{Tg} \mathrm{CO}_{2}$-e in 2020 and 142,586 , and $1,164 \mathrm{Tg} \mathrm{CO}_{2}$-e in 2030. The data in Table 2 provide details on emissions of greenhouse gases from several systems of beef and milk production. Despite a wide range of scopes and a broad variability in occupied procedures for monitoring and calculation, resulting in varied outcomes, there is an overall consensus that the major sources of greenhouse gases in this sector are related to field operations for growing feed, enteric fermentation, and manure storing and treatment. Also, Naylor et al. (2005) stressed that in addition to greenhouse gases, industrial livestock operations also require large amounts of water especially for feed production and that water quality is reduced through the release of nutrients, pathogens, antibiotics, and other chemicals via return flows.

The energy requirements and greenhouse gas emissions in production of animal source foods (ASF) are much greater than in production of other food products, including grains, vegetables, and fruits. For example, Fiala (2009) studied the impact of several food products on greenhouse gases and found that emissions from production of potatoes, apples, and asparagus are $0.12,0.14$, and $0.18 \mathrm{~kg} \mathrm{CO}_{2}-\mathrm{e} \mathrm{kg}^{-1}$, respectively, compared to $0.49,1.72$, and $6.71 \mathrm{~kg} \mathrm{CO}_{2}$-e kg ${ }^{-1}$ for chicken, pork, and beef, respectively. This corresponds to the 


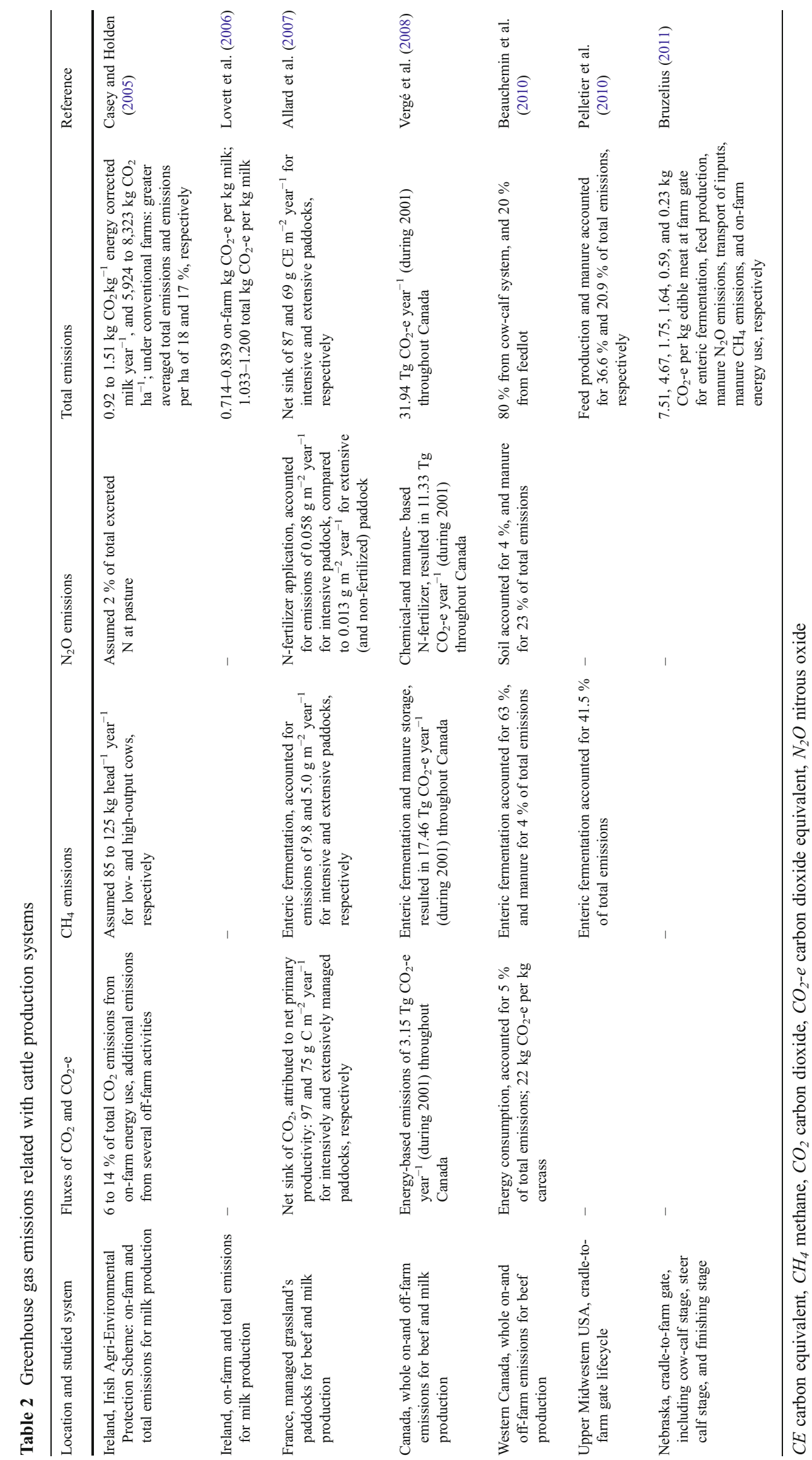


feed conversion ratio, calculated as the proportion between consumed cereal weight and animal weight, which was reported as 1.7, 2.43, and 5-10 for chicken, pork, and beef, respectively (Garnett 2009). Protein delivery efficiency was reported to be of 4.4, 7.3, and $7.0 \mathrm{~g}$ protein $\mathrm{MJ}^{-1}$ of energy invested for beef, pork, and chicken, respectively. Protein delivery efficiency of eggs and milk was calculated as 9 and 11 , respectively. Much greater protein delivery efficiency was reported for cereals -8 to $57 \mathrm{~g}$ protein $\mathrm{MJ}^{-1}$ and for legumes 41 to $77 \mathrm{~g}$ protein $\mathrm{MJ}^{-1}$. However, for vegetables and fruits, protein delivery efficiency ranged between $2.6-15$ and $0.7-$ $2.7 \mathrm{~g}$ protein $\mathrm{MJ}^{-1}$, respectively (González et al. 2011).

\section{Climate change impact on agricultural productivity}

Assessing the impact of climate change on agricultural productivity is a challenging task as the influences of nonclimate factors, mainly advances in agronomy and soil management technologies, are also involved (Rosenzweig et al. 2007). Moreover, some climatic factors have contradictory effects on agricultural production. For example, the higher atmospheric $\mathrm{CO}_{2}$ concentrations are expected to have a positive impact on crops, known as the $\mathrm{CO}_{2}$ Fertilization Effect. This is because plants respond to elevated $\mathrm{CO}_{2}$ by partially closing their stomata, which reduces transpiration loss and increases water-use efficiency (Bindi and Howden 2008). However, the magnitude of this effect is less clear, with differences depending on management practices and crop type (Long et al. 2004). For example, the positive effect on photosynthesis is more relevant for $\mathrm{C}_{3}$ than for $\mathrm{C}_{4}$ plants that have a more efficient photosynthetic pathway under current atmospheric $\mathrm{CO}_{2}$ concentrations (Bindi and Howden 2008). Large-scale experimentations have revealed that under optimal growth conditions, elevated $\mathrm{CO}_{2}$ concentration of $550 \mathrm{ppm}$ can increase yields by $10-20 \%$ for $\mathrm{C}_{3}$ crops such as wheat, rice, and soybean, compared with only $0-10 \%$ for $\mathrm{C}_{4}$ crops such as corn and sorghum (Ainsworth et al. 2004; Long et al. 2004). Also, reduced stomatal conductance under higher $\mathrm{CO}_{2}$ conditions may have implications for heat stress as leaf temperature rises with reduced transpiration (Vadez et al. 2012).

In addition to $\mathrm{CO}_{2}$, climate change directly impacts agricultural productivity through increase in temperature. In humid temperate latitudes, higher temperatures are expected to benefit agricultural production by expanding areas potentially suitable for croplands, as well as by extending length of the growing season (Rosenzweig et al. 2007). At the same time, the expected high frequency of heavy rain storms in these regions could increase the rate and magnitude of floods and erosional processes (WMO 2011). Also, despite the favorable impact of temperature rise on crop production capacity in these regions, it may also increase infestation of pests and diseases, augmenting potential damages to crops (Rosenzweig et al. 2007). For example, a survey to assess winter mortality of rice bugs and fruit bugs in Japan revealed that every $1{ }^{\circ} \mathrm{C}$ rise in mean winter temperature resulted in a reduction of $\sim 15 \%$ in mortality of the pests Nezara viridula and Halyomorpha halys in locations where the mean winter temperature ranges from 2 to $6{ }^{\circ} \mathrm{C}$ (Kiritani 2007). The projected climate change can affect plant pathosystems at various levels, namely from genes to populations and from ecosystem to distributional ranges. Furthermore, climate changes may also have a profound effect on geographical distribution of host and pathogens, physiology of host-pathogen interactions, rate of development of pathogens, transmission and dispersal of pathogens, and emergence of new diseases (Vadez et al. 2012).

In Mediterranean and semi-arid regions, the expected increased frequency of extreme warm episodes and droughts (WMO 2011) will considerably increase moisture loss through evapotranspiration, thereby decreasing the wateruse efficiency. This is in part due to the higher vapor pressure deficit conditions, which will impose high plantatmosphere pressure gradients and drive water out of the leaves at a faster rate, leading to more rapid depletion of the soil moisture. Temperature rise in these regions could, therefore, trigger modifications in crop phenology: the higher temperatures are expected to precede the onset of flowering, while reducing the length of the growing period due to the increased evapotranspiration (Vadez et al. 2012). At the same time, increased frequency of extreme rain storms in some of these regions may increase their vulnerability to devastating erosional processes (Cudennec et al. 2007; Fig. 5). In the African tropics and subtropics, projected magnitude of rainfall changes for 2050 is small in most

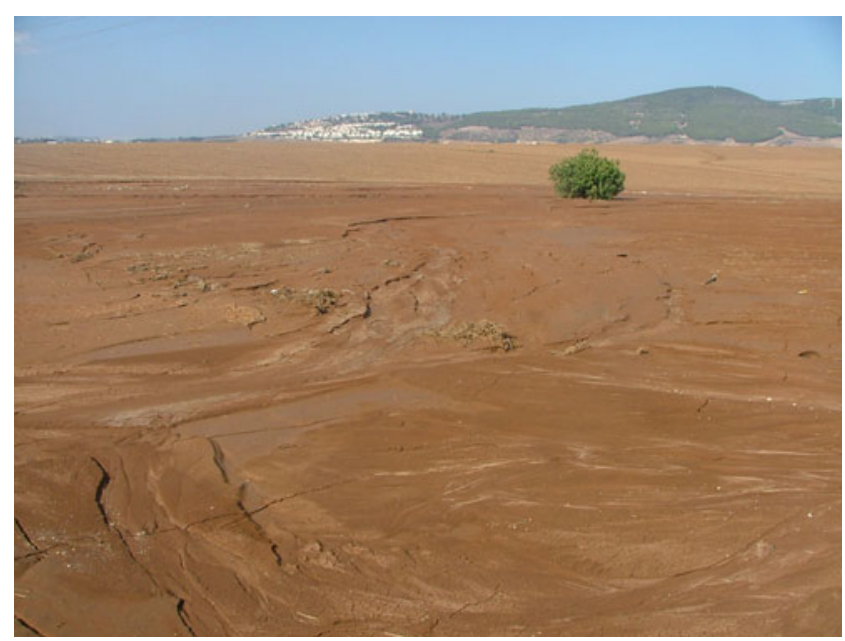

Fig. 5 Extensive soil erosion from croplands following extreme rain showers, northern Israel. Photographed by I. Stavi 
areas but may increase up to $20 \%$ of $1961-1990$ baseline values in some regions. In addition, climate change will have strong harmful impacts on agricultural productivity, even with only a small increase in average temperature. Overall, warming and shifts in precipitation regimes are projected to decrease crop yields over a wide range in the next decades throughout most of the tropical and subtropical African regions, ranging between a $3 \%$ drop to almost total failure. Yet, in some of these African regions, climatic changes may increase crop yields to a rate of between 3 and $16 \%$ (Challinor et al. 2007).

The impact of global warming on SOC dynamics is also an issue of global importance. In a synthesis study that analyzed data obtained from 1989 through 2008, BondLamberty and Thomson (2010) reported that detritivore respiration is highly correlated with an increase in temperatures. However, they concluded that the increased respiration rate is not necessarily induced directly by climate change but rather by higher inputs of organic $\mathrm{C}$ to soil. In a study on the impact of $5{ }^{\circ} \mathrm{C}$ rise on soil microbial activity, Allison et al. (2010) reported that despite an initial increase in respiration rate, it declined back to the initial level within a few years. Allison and colleagues attributed this response to modifications in detritivore physiological characteristics with increasing temperature, such as a decline in the fraction of assimilated $\mathrm{C}$ that is allocated to growth. The reduced Cuse efficiency limited the microbial biomass, thus mitigating decomposition rates of SOC. Yet, Allison and colleagues added that microbial adaptation or a change in detritivore communities could lead to improved $\mathrm{C}$ use efficiency, counteracting the decrease in microbial biomass and increasing the rates of SOC decomposition.

In addition to the impact on agroecosystems, climate changes also substantially alter some semi-natural ecosystems. Such alterations may impact the global livestock sector due to decreased availability of feed and pastures (Thornton and Gerber 2010). Also, climate change may have significant impacts on the emergence, spread, and distribution of livestock diseases because higher temperatures may increase the rate of development of pathogens and parasites through several pathways: first, by affecting hosts, such as shifts in disease distribution that may impact susceptible animal populations; second, by affecting vectors, such as changes in rainfall and temperature regimes that can impact distribution and abundance of diseases; and third, by affecting epidemiology, such as altered transmission rates between hosts (Randolph 2008). Because of these impacts, vulnerability of households dependent on livestock is likely to increase substantially, with concomitant exacerbated poverty and inequity. This is particularly relevant in relatively dry areas of developing countries (Thornton et al. 2009).

\section{Management, policy, and regulations}

The interrelations among agricultural production, environmental sustainability, and economic viability of low-income populations throughout the world need a more prominent position in future discussions on global changes (Ziesemer 2007). The rising prices of fuels and fertilizers increased the world food prices by $\sim 140 \%$ between 2002 and 2007. In 2007 , the number of malnourished people in the world totaled $\sim 923$ million. The food price crisis in 2008 added another 100 million to the world's malnourished (OFID 2009). Yet, since the late 1990s, the increased economic power of some populations in the developing world raised the pressure on the globe's natural resources (Delgado 2003).

It is indeed the misconception of the atmosphere as an infinite and toll-free resource which has led to enormous anthropogenic emissions of greenhouse gases, aggravating global warming and exacerbating environmental change. The projected growth of human population to between 8.1 and 10.6 billion by 2050 (UN 2011) is expected to considerably exacerbate greenhouse gas emissions and increase the pressure on natural resources. Therefore, one of the main challenges for national and international policy makers is to increase food security while reducing emissions of greenhouse gases and decreasing the total environmental footprint of agriculture. However, it seems that unless global demand for food is decreased, the conversion of uncultivated land to arable lands and grazing lands will continue and agricultural practices will become more intensive. Therefore, considerable efforts should be directed at encouraging the relevant sectors to adopt conservation farming practices, aimed at increasing efficiency and decreasing emissions of greenhouse gases related with agricultural production, while recovering environmental services.

In croplands, the required modifications could be implemented through several conservation means such as reduced tillage or no-till (NT) systems (Fig. 6). The energy use under NT systems requires 50 to $80 \%$ less fuel than that under intensive tillage systems (Huggins and Reganold 2008). While emissions of greenhouse gases for seedbed preparation are $\sim 35 \mathrm{~kg} \mathrm{CE} \mathrm{ha}^{-1}$ for intensive tillage, they encompass only $\sim 8 \mathrm{~kg} \mathrm{CE} \mathrm{ha}{ }^{-1}$ for reduced tillage and $\sim 6 \mathrm{~kg} \mathrm{CE} \mathrm{ha}^{-1}$ for NT (Lal 2004). Also, NT reduces total costs, as work force can be reduced by 30 to $50 \%$ under these systems compared to intensive tillage systems (Huggins and Reganold 2008). In addition, NT reduces the adverse impacts of tillage by increasing the soil macroaggregation processes and lessening of SOC oxidation. The increased SOC concentration enhances microbial productivity, improves soil fertility, and decreases its erodibility (Lal et al. 2004). Other means include improved nutrient management and integrated pest management, which 


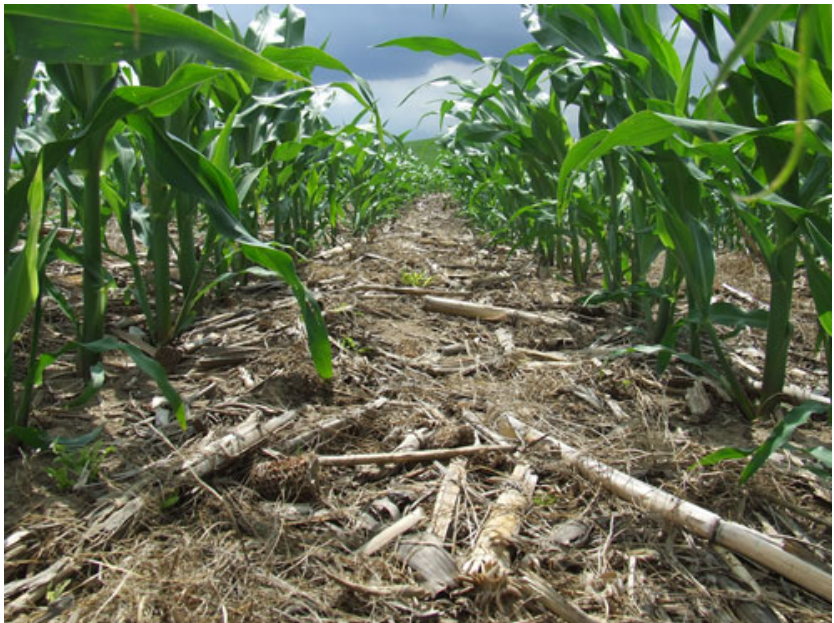

Fig. 6 Continuous corn cropping under no-till system, eastern Ohio, Midwest USA. Note the corn residues of the previous year covering the soil surface. Photographed by I. Stavi

decrease agricultural inputs and reduce off-farm and onfarm emissions of greenhouse gases (Lal 2009). Conversion from inorganic to organic farming could reduce total (combined off-farm and on-farm) energy input, as organic agriculture uses between 30 and $50 \%$ less fossil fuel-based inputs (Ziesemer 2007). Also, despite $30 \%$ smaller energy output under organic systems, their energyuse efficiency could be up to $40 \%$ greater than that under inorganic systems (Hoeppner et al. 2006). Yet, the lower crop yields with organic farming would necessitate bringing more land under cultivation. Also, an economic burden in wide adoption of organic farming relates to the high input of on-farm human labor that requires a 30 to $35 \%$ increase as opposed to inorganic farming (Ziesemer 2007). In addition, over reliance on tillage for weed control increases risk of soil erosion (Hoeppner et al. 2006) and augments oxidation of SOC.

A specific management practice for improving soil quality and productive capacity could be the utilization of biochar - the solid by-product of the C-negative pyrolysis process for production of bio-energy from biomass - as a soil amendment. This management practice was reported to increase the recalcitrant fraction of SOC and decrease emissions of greenhouse gases from soil (Lee et al. 2010). At the same time, biochar application amplifies the soil's cation exchange capacity and retention of nutrients, augmenting their availability for plants (Laird et al. 2010). Another option is the combining of trees with field crops under agro-forestry systems (Fig. 7). That would further boost C sequestration capacity of agriculture (Stavi and Lal 2012) and at the same time provide variety of products from a land unit, augment fertilizer efficiency, and improve natural pest control (Nair et al. 2010). Also, wise adoption of precision agriculture's technologies would considerably increase

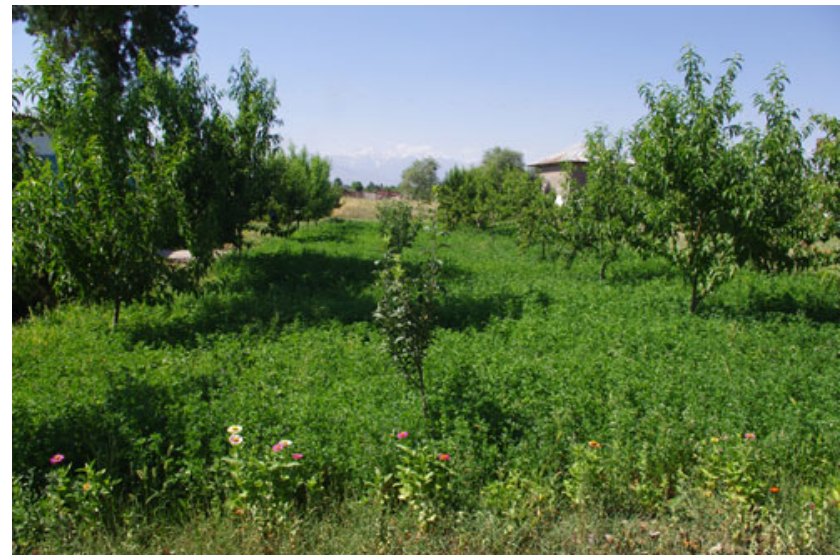

Fig. 7 Agroforestry system, comprised of apricot (Prunus armeniaca) trees in the outer rows and apple (Malus domestica) trees in the central row, with alfalfa (Medicago sativa) as an intercrop. Photographed in western Tajikistan by I. Stavi

efficiency and would, therefore, reduce inputs of fuel, fertilizer, herbicides, and pesticides and minimize the environmental footprint of farmlands (Bongiovanni and Lowenberg-Deboer 2004). Overall, the implementation of conservation practices, entitled best management practices (BMPs), is expected to decrease emissions of greenhouse gases, minimizing the impact of agriculture on climate change (Soil Conservation Council of Canada 2003). In order to be effective in mitigating the adverse environmental impact of agriculture, BMPs should be implemented concordantly with increasing energy efficiency in farming systems.

However, since the advantages for individuals from such modifications being obscure in some cases, it seems unlikely that behavioral changes can happen voluntarily. Therefore, motivation should be reinforced through national and international regulations and active policy tools, aimed at providing economic incentives for reducing the environmental footprint of agriculture. An efficient mechanism could be initiated through payments for improving ecosystem services (FAO 2007). Of these, the most relevant is decreasing greenhouse gas emissions. Popp et al. (2010) emphasized that putting a price on greenhouse gas emissions via a tax or emission trading scheme is an economically sound strategy for addressing the adverse externalities of greenhouse gases. Additional services include maintaining quality of water sources, soil erosion control, and biodiversity conservation. Yet, key challenges in implementing this approach include creating a mechanism for valuing a service and identifying how additional amounts of that service can be provided most cost-effectively. Also, payments are only one of the potential tools for improving environmental services. Others include information provision, policy reforms to reduce market distortions, command-and-control 
regulations, and taxation (FAO 2007). In addition, future research and development should be aimed at providing the basis for energy-reducing technologies, as well as policies that prioritize energy efficiency in all stages of food production (Ziesemer 2007).

An especially noteworthy alternative for providing a replacement for fossil fuels is the emerging sector of bioenergy and biofuels. Because of an enthusiastic global response, it is pertinent to highlight several associated concerns that are related to environmental sustainability and global food security. Biofuels are being considered for the aim of addressing the challenges of climate change, energy security, and rural development. The interest in biofuels has been accelerated by governmental policies and support measures, such as time-bound targets for biofuels consumption. Commercial agriculture has embraced this opportunity of assured long-term governmental support and responded with investments to increase production for meeting the market demand for biofuel feedstocks. This has resulted in increased market prices of current firstgeneration biofuels feedstocks that are also important food and feed crops, including sugar cane (Saccharum spp.), corn, cassava (Manihot esculenta), rapeseed (Brassica napus L.), oil palm (Elaeis spp.), and soybean. Among the non-edible first-generation biofuels, jatropha (Jatropha spp.) is of special importance. Among second-generation biofuels, different woody and herbaceous lignocellulosic feedstocks are considered as commercial crops. The current share of $\sim 1.5 \%$ of biofuels in the total fuel consumption for transportation is expected to increase by 2020 to 6 and $8 \%$ in the developing and developed world, respectively. The corresponding shares by 2030 are expected to increase to 8 and $12 \%$, respectively (OFID 2009). However, the rapid evolvement of the bioenergy sector has resulted in numerous environmental and socioeconomic challenges. First, in order to become environmentally justified, biofuels must be produced with lower life-cycle greenhouse gas emissions than fossil fuels (Tilman et al. 2009). Calculations of the emission of greenhouse gases must include emissions during all stages, including the production and transportation of feedstocks, conversion of feedstocks to biofuels, distribution of biofuels to end users, and final use (OFID 2009). A recent report by OFID (2009) showed that net greenhouse gas savings through biofuels can only be expected 30 to 50 years after land-use conversion. Over shorter periods, net greenhouse gas balances are dominated by $\mathrm{C}$ debts due to direct and indirect impacts of land-use changes. Fargione et al. (2008) showed that clearing of forests, savannas, grasslands, or peatlands releases 17 to 420 times more $\mathrm{CO}_{2}$ than the annual greenhouse gas reductions that biofuels grown on these lands would provide by displacing fossil fuels. Another major challenge is that the massive conversion of lands from food production to biofuels decreases world's food supply and accelerates an increase in food prices (OFID 2009; Biello 2011).

Therefore, public regulations should ensure that biofuels receive policy support as substitutes for fossil energy only when they optimize several benefits, including real energy gains and greenhouse gas reductions and assure the preservation of biodiversity and sustaining of food security (Tilman et al. 2009). For example, corn ethanol, so far the only biofuel to reach commercial scale in the USA, has proved many times to be C-positive (Fargione et al. 2008; Biello 2011), doubling greenhouse gases over 30 years after land clearing and increasing emissions for additional $\sim 130$ years (Searchinger et al. 2008). In production of corn ethanol, a great deal of energy is required to distill the ethanol from the blend of water and yeast in which it has been fermented. The energy for this process is typically supplied by burning fossil fuels such as natural gas or coal that cost money as well. In addition to this, a gallon of ethanol produces only two thirds of the energy produced by a gallon of gasoline. Therefore, corn ethanol may never compete in price with gasoline without subsidies (Biello 2011). Even the perennial switchgrass (Panicum virgatum L.), if grown on lands previously planted with corn, increases emissions by $50 \%$ over 30 years after land-use change (Searchinger et al. 2008). As opposed to these, perennial grasses grown on degraded or abandoned lands could be C-neutral and even C-negative (Fargione et al. 2008). Specifically, mixtures of native perennial grasses grown on degraded lands and which require almost no fertilizer and no herbicides at all proved to be highly efficient, producing up to $\sim 240 \%$ more biomass than monoculture crops and with an energy gain of approximately three times that of corn ethanol and switchgrass. Under such scenarios, these grasses would not compete with food production (Tilman et al. 2006) and could be considered legitimate candidate for support. Moreover, if managed properly, use of such lands for perennial grasses would restore wildlife habitat, improve water quality, and sequester $\mathrm{C}$ in soil (Tilman et al. 2006, 2009).

As regards ASF, despite the fact that their consumption rates in developing countries have increased from rather low levels of the past, they still have a long way to go before approaching the averages in developed countries. Nevertheless, in many cases, these dietary changes have created serious environmental challenges. For example, the projected increase in livestock production will require annual feed consumption of cereals to rise tremendously and especially so in the developing world. To some extent, this is attributed to the incomes and nutrition of millions of poor people in developing countries that have been improving considerably. It was shown that the per capita consumption of ASF is increasing at the fastest rate in regions where urbanization and rapid 
income growth are also happening. For instance, in East and Southeast Asia-where income grew at 4-8\% annually between the early 1980s and 1998, population at 2-3\% annually, and urbanization at 4-6\% annually-meat consumption grew between $4-8 \%$ annually (Delgado 2003). The adverse impact of livestock on global warming could be mitigated through several pathways. First, wise implementation of the BMPs would decrease emissions of greenhouse gases related to feed production. Second, changes in animals' diet could considerably reduce direct emissions from livestock. For example, about $50 \%$ reduction of $\mathrm{CH}_{4}$ emission from cattle could be achieved by grazing in high quality rather than in low-quality pastures. Also, adding as little as $25 \%$ legumes to forage would further reduce $\mathrm{CH}_{4}$ emissions (Soil Conservation Council of Canada 2003). Another potential pathway is through utilizing $\mathrm{CH}_{4}$-capturing systems and using the $\mathrm{CH}_{4}$ to generate electricity. However, these systems are still too costly to be commercially viable (Fiala 2009). Also, there are some management options to minimize emissions of greenhouse gases from animal wastes. For example, the use of covers in liquid manures may reduce up to $95 \%$ of $\mathrm{CH}_{4}$ emissions. Other waste treatments include managing $\mathrm{pH}$, shortening storage time, and choosing the best timing for application in croplands, further reducing emissions of greenhouse gases (Soil Conservation Council of Canada 2003).

Similarly to the croplands sector, the meat sector also requires significant regulations. These are needed in order to make the necessary link between livestock production and its related environmental footprint. Currently, trade in meat products obscures the environmental cost of livestock production, particularly for meat importers. The importers pay for the direct costs of production and transportation, but do not pay for the external environmental costs, such as degraded water quality, biodiversity loss, and emissions of greenhouse gases (Naylor et al. 2005). Concordantly with such regulations, publicity and educational efforts on national and international levels should be directed at generating positive public opinion, aimed at reducing meat consumption. A recent modeling study showed that a global dietary change toward a low meat consumption could lead to the abandonment of up to 2,700 Mha of pasture and 100 Mha of cropland, resulting in a large $C$ uptake from regrowth of vegetation and reducing mitigation costs to achieve a $450 \mathrm{ppm} \mathrm{CO} \mathrm{CO}_{2}$-e (Stehfest et al. 2009). This would help in fulfilling the long-term climate target adopted by the United Nations of limiting temperature increase to less than $2{ }^{\circ} \mathrm{C}$ compared to pre-industrial levels with a chance of $\sim 50 \%$ (based on probability distribution functions for climate sensitivity) (IPCC 2007). Another study modeled several dietary change scenarios and revealed that a drastic decadal reduction in global demand for meat products by $25 \%$ would lead to a total decrease of non- $\mathrm{CO}_{2}$ emissions in
2055 by $51 \%$ compared to the 1995 baseline (Popp et al. 2010). However, similar to the required modifications in crop production systems, the good will of individuals may not be enough to generate the desired dietary changes, preventing the wide adoption of low-meat diets. In this regard, Naylor et al. (2005) proposed that a recoupling mechanism of crop and livestock systems needs to be implemented through pricing and other policy tools that reflect costs of resource use and environmental abuse. Such a mechanism could be perceived as a legitimate environmental tax and would be expected to reduce consumption of meat products and to lower the environmental footprint of livestock systems. Yet, it is hereby stressed that such tools should be well managed in order to prevent an increase in inequality between wealthy populations and those which are impoverished and already prone to malnutrition. For that reason, such mechanisms need to be operated and effectively controlled through national and international policies in order to regulate meat consumption among numerous socioeconomic groups around the world. The collected tax then could be allocated for projects aimed at sequestering $\mathrm{C}$ and restoring environmental services in agriculturally-damaged areas worldwide.

\section{Conclusions}

The well-known concept "The Tragedy of the Commons" was previously suggested to highlight the over-exploitation of public resources due to their common nature. In this review, we broadened this concept to include anthropogenic emissions of greenhouse gases to the atmosphere, and specifically, we focused on the impacts of agriculture.

Intensive farming practices of field crops production and livestock husbandry increase the pressure on natural environments and augment emissions of greenhouse gases. Principal factors in field crop production are fuel consumption and tillage operations which result in emission of $\mathrm{CO}_{2}$ and oxidation of SOC, respectively. Also, application of $\mathrm{N}$ fertilizers leads to emissions of $\mathrm{N}_{2} \mathrm{O}$. In the livestock sector, the main issues are the high input of energy, as well as the decreased efficiency of energy conversion along the food chain. A specific impact of livestock industry is the emission of $\mathrm{CH}_{4}$ from ruminants. Together, cropland farming and livestock husbandry account for a considerable share of global anthropogenic emissions of greenhouse gases, as well as for several adverse impacts on environmental services. The growth of human population and the increased demand for food products boosts the need for regulations, aimed at augmenting the adoption of conservation agricultural practices and, at the same time, encouraging the spread of environmentally sound diets. Concordantly, international mechanisms should form effective policies for increasing 
nutritional equality and global food security, while restoring the environmental footprint of agriculture.

\section{References}

Ainsworth EA, Rogers A, Nelson R, Long SP (2004) Testing the "source-sink" hypothesis of down-regulation of photosynthesis in elevated $\left[\mathrm{CO}_{2}\right]$ in the field with single gene substitutions in Glycine max. Agr Forest Meteorol 122:85-94. doi:10.1016/ j.agrformet.2003.09.002

Allard V, Soussana JF, Falcimagne R, Berbigier P, Bonnefond JM, Ceschia E, D'hour P, He'nault C, Laville P, Martin C, Pinare'sPatino $C$ (2007) The role of grazing management for the net biome productivity and greenhouse gas budget $\left(\mathrm{CO}_{2}, \mathrm{~N}_{2} \mathrm{O}\right.$ and $\mathrm{CH}_{4}$ ) of semi-natural grassland. Agr Ecosyst Environ 121:47-58. doi:10.1016/j.agee.2006.12.004

Allison SD, Wallenstein MD, Bradford MA (2010) Soil-carbon response to warming dependent on microbial physiology. Nature Geosci 3:336-340. doi:10.1038/NGEO846

Beauchemin KA, Janzen HH, Little SM, McAllister TA, McGinn SM (2010) Life cycle assessment of greenhouse gas emissions from beef production in western Canada: a case study. Agr Syst 103:371-379. doi:10.1016/j.agsy.2010.03.008

Biello D (2011) The false promise of biofuels - the breakthroughs needed to replace oil with plant-based fuels are proving difficult to achieve. Sci Am 305:58-65. doi:10.1038/scientificamerican0811-58

Bindi M, Howden SM (2008) Food crops under global warming and changing water availability. In: An International Meeting of the Water Tribune of Expozaragoza. Zaragoza

Bond-Lamberty B, Thomson A (2010) Temperature-associated increases in the global soil respiration record. Nature 464:579582. doi: 10.1038 /nature 08930

Bongiovanni R, Lowenberg-Deboer J (2004) Precision agriculture and sustainability. Precis Agr 5:359-387

Bruzelius N (2011) Meat eater's guide to climate change + health. Lifecycle assessments: methodology \& results. Environmental Working Group, Washington, DC

Casey JW, Holden NM (2005) The relationship between greenhouse gas emissions and the intensity of milk production in Ireland. $\mathrm{J}$ Environ Qual 34:429-436

Challinor A, Wheeler T, Garforth C, Craufurd P, Kassam A (2007) Assessing the vulnerability of food crop systems in Africa to climate change. Clim Chang 83:381-399. doi:10.1007/s10584007-9249-0

Clements DR, Weise SF, Brown R, Stonehouse DP, Hume DJ, Swanton CJ (1995) Energy analysis of tillage and herbicide inputs in alternative weed management systems. Agr Ecosyst Environ 52:119-128. doi:10.1016/0167-8809(94)00546-Q

Committee on Environment and Natural Resources (2010) Scientific assessment of hypoxia in U.S. coastal waters. Interagency Working Group on Harmful Algal Blooms, Hypoxia, and Human Health of the Joint Subcommittee on Ocean Science and Technology, Washington, DC

Cudennec C, Leduc C, Koutsoyiannis D (2007) Dryland hydrology in Mediterranean regions - a review. Hydrolog Sci J 52:1077-1087

DeAngelo BJ, de la Chesnaye FC, Beach RH, Sommer A, Murray BC (2006) Methane and nitrous oxide mitigation in agriculture. Energy J 3:89-108

de Jong B, Anaya C, Masera O, Olguín M, Paz F, Etchevers J, Martínez DR, Guerrero G, Balbontín D (2010) Greenhouse gas emissions between 1993 and 2002 from land-use change and forestry in Mexico. Forest Ecol Manag 260:1689-1701. doi:10.1016/j.foreco.2010.08.011

Delgado CL (2003) Rising consumption of meat and milk in developing countries has created a new food revolution. J Nutr 133:3907S-3910S

FAO (2006) World agriculture: towards 2030/2050. Interim report. Food and Agriculture Organization of the United Nations, Rome

FAO (2007) The state of food and agriculture - paying farmers for environmental services. FAO Agriculture series no. 38. Food and Agriculture Organization of the United Nations, Rome

Fiala N (2008) Meeting the demand: an estimation of potential future greenhouse gas emissions from meat production. Ecol Econ 67:412-419. doi:10.1016/j.ecolecon.2007.12.021

Fiala N (2009) The greenhouse hamburger. Sci Am 300:72-75. doi:10.1038/scientificamerican0209-72

Fargione J, Hill J, Tilman D, Polasky S, Hawthorne P (2008) Land clearing and the biofuel carbon debt. Science 319:1235-1238. doi: $10.1126 /$ science. 1152747

Franzluebbers AJ, Schomberg HH, Endale DM (2007) Surface-soil responses to paraplowing of long-term no-tillage cropland in the Southern Piedmont USA. Soil Tillage Res 96:303-315. doi:10.1016/j.still.2007.07.001

Garnett T (2009) Livestock-related greenhouse gas emissions: impacts and options for policy makers. Environ Sci Policy 12:491-503. doi:10.1016/j.envsci.2009.01.006

González AD, Frostell B, Carlsson-Kanyama A (2011) Protein efficiency per unit energy and per unit greenhouse gas emissions: potential contribution of diet choices to climate change mitigation. Food Policy 36:562-570. doi:10.1016/j.foodpol.2011.07.003

Harden JW, Berhe AA, Torn M, Harte J, Liu S, Stallard RF (2008) Soil erosion: data say C sink. Science 320:178-179. doi:10.1126/ science.320.5873.178

Hardin G (1968) The tragedy of the commons. Science 162:1243-1248

Hoeppner JW, Entz MH, McConkey BG, Zentner RP, Nagy CN (2006) Energy use and efficiency in two Canadian organic and conventional crop production systems. Renew Agr Food Syst 21:60-67. doi:10.1079/RAF2005118

Huggins DR, Reganold JP (2008) No-till: the quiet revolution. Sci Am 299:70-77. doi:10.1038/scientificamerican0708-70

Hutchinson JJ, Campbell CA, Desjardins RL (2007) Some perspectives on carbon sequestration in agriculture. Agr Forest Meteorol 142:288-302. doi:10.1016/j.agrformet.2006.03.030

IPCC (2007) Climate change 2007. The physical science basis. In: Solomon S, Qin D, Manning M, Chen Z, Marquis M, Averyt KB, Tignor M, Miller HL (eds) Contribution of working group I to the fourth assessment report of the intergovernmental panel on climate change. Cambridge University Press, New York

Kauffman JB, Steele MD, Cummings DL, Jaramillio VJ (2003) Biomass dynamics associated with deforestation, fire, and conversion to cattle pasture in a Mexican tropical dry forest. Forest Ecol Manag 176:1-12. doi:10.1016/S0378-1127(02)00227-X

Kiritani K (2007) The impact of global warming and land-use change on the pest status of rice and fruit bugs (Heteroptera) in Japan. Glob Change Biol 13:1586-1595. doi:10.1111/ j.1365-2486.2007.01397.x

Kögel-Knabner I, Amelung W, Cao Z, Fiedler S, Frenzel P, Jahn R, Kalbitz K, Kölbl A, Schloter M (2010) Biogeochemistry of paddy soils. Geoderma 157:1-14. doi:10.1016/j.geoderma.2010.03.009

Laird D, Fleming P, Wang B, Horton R, Karlen D (2010) Biochar impact on nutrient leaching from a Midwestern agricultural soil. Geoderma 158:436-442. doi:10.1016/j.geoderma.2010.05.012

Lal R (2003) Soil erosion and the global carbon budget. Environ Int 29:437-450. doi:10.1016/S0160-4120(02)00192-7

Lal R (2004) Carbon emission from farm operations. Environ Int 30:981-990. doi:10.1016/j.envint.2004.03.005 
Lal R, Griffin M, Apt J, Lave L, Morgan G (2004) Response to comments on "Managing soil carbon". Science 305:1567-1568. doi:10.1126/science.1101271

Lal R (2007) Tragedy of the global commons: soil, water and air. CSA News V52(N10):10-11

Lal R, Follett RF, Stewart BA, Kimble JM (2007) Soil carbon sequestration to mitigate climate change and advance food security. Soil Sci 172:943-956. doi:10.1097/ss.0b013e31815cc498

Lal R (2009) Challenges and opportunities in soil organic matter research. Eur J Soil Sci 60:158-169. doi:10.1111/j.1365-2389.2008.01114.x

Lee JW, Hawkins B, Day DM, Reicosky DC (2010) Sustainability: the capacity of smokeless biomass pyrolysis for energy production, global carbon capture and sequestration. Energy Environ Sci 3:1695-1705. doi:10.1039/C004561F

Lobb D (1989) A study of the impact of no-till on tractor fuel cost vs. crop returns as affected by various no-till planter modifications. Agricultural Energy Centre of the Ontario Ministry of Agriculture and Food, Toronto

Long SP, Ainsworth EA, Rogers A, Ort DR (2004) Rising atmospheric carbon dioxide: plants FACE the future. Annu Rev Plant Biol 55:591-628. doi:10.1146/annurev.arplant.55.031903.141610

Lovett DK, Shalloo L, Dillon P, O’Mara FP (2006) A systems approach to quantify greenhouse gas fluxes from pastoral dairy production as affected by management regime. Agr Syst 88:156-179. doi:10.1016/j.agsy.2005.03.006

Matsumoto N, Paisancharoen K, Hakamata T (2008) Carbon balance in maize fields under cattle manure application and no-tillage cultivation in northeast Thailand. Soil Sci Plant Nutr 54:277288. doi:10.1111/j.1747-0765.2007.00223.x

Meyerson FAB (1998) Population, development and global warming: averting the tragedy of the climate commons. Popul Environ 19:443-463. doi:10.1023/A:1024622220962

Moebius-Clune BN, van Es HM, Idowu OJ, Schindelbeck RR, Moebius-Clune DJ, Wolfe DW, Abawi GS, Thies JE, Gugino BK, Lucey R (2008) Long-term effects of harvesting maize stover and tillage on soil quality. Soil Sci Soc Am J 72:960-969. doi:10.2136/sssaj2007.0248

Nair PKR, Nair VD, Kumar BM, Showalter JM (2010) Carbon sequestration in agroforestry systems. Adv Agron 108:237-307. doi:10.1016/S0065-2113(10)08005-3

Naylor R, Steinfeld H, Falcon W, Galloway J, Smil V, Bradford E, Alder J, Mooney H (2005) Losing the links between livestock and land. Science 310:1621-1622. doi:10.1126/science.1117856

Nelson RG, Hellwinckel CM, Brandt CC, West TO, De La Torre Ugarte DG, Marland G (2009) Energy use and carbon dioxide emissions from cropland production in the United States, 1990 2004. J Environ Qual 38:418-425. doi:10.2134/jeq2008.0262

OFID (2009) Biofuels and food security-implications of an accelerated biofuels production. Summary of the OFID study prepared by IIASA. The OPEC Fund for International Development, Vienna

Pelletier N, Pirog R, Rasmussen R (2010) Comparative life cycle environmental impacts of three beef production strategies in the Upper Midwestern United States. Agr Syst 103:380-389. doi:10.1016/j.agsy.2010.03.009

Perdomo C, Irisarri P, Ernest O (2009) Nitrous oxide emission from an Uruguayan argiudoll under different tillage and rotation treatments. Nutr Cycling Agroecosyst 84:119-128. doi:10.1007/ s10705-008-9231-x

Popp A, Lotze-Campen H, Bodirsky B (2010) Food consumption, diet shifts and associated non- $\mathrm{CO}_{2}$ greenhouse gases from agricultural production. Global Environ Chang 20:451-462. doi:10.1016/ j.gloenvcha.2010.02.001

Price L, de la Rue du Can S, Sinton J, Worrell E, Nan Z, Sathaye J, Levine M (2006) Sectoral trends in global energy use and greenhouse gas emissions. Ernest Orlando Lawrence Berkeley National Laboratory, Berkeley
Randolph SE (2008) Dynamics of tick-borne disease systems: minor role of recent climate change. Revue Scientifique et TechniqueOffice International des Epizooties 27:367-381

Refsgaard K, Halbergb N, Kristensenb ES (1998) Energy utilization in crop and dairy production in organic and conventional livestock production systems. Agr Syst 57:599-630. doi:10.1016/S0308521X(98)00004-3

Rosenzweig C, Casassa G, Karoly DJ, Imeson A, Liu C, Menzel A, Rawlins S, Root TL, Seguin B, Tryjanowski P (2007) Assessment of observed changes and responses in natural and managed systems. In: Parry ML, Canziani OF, Palutikof JP, van der Linden PJ, Hanson CE (eds) Climate change 2007: impacts, adaptation and vulnerability. Contribution of Working Group II to the Fourth Assessment Report of the Intergovernmental Panel on Climate Change. Cambridge University Press, Cambridge, pp 79-131

Schneider UA, Smith P (2009) Energy intensities and greenhouse gas emission mitigation in global agriculture. Energy Efficiency 2:195-206. doi:10.1007/s12053-008-9035-5

Searchinger T, Heimlich R, Houghton RA, Dong F, Elobeid A, Fabiosa J, Tokgoz S, Hayes D, Yu TH (2008) Use of U.S. croplands for biofuels increases greenhouse gases through emissions from land-use change. Science 319:1238-1240. doi:10.1126/science. 1151861

Six J, Elliot ET, Paustin K (2000) Soil macroaggregate turnover and microaggregate formation: a mechanism for $\mathrm{C}$ sequestration under no-tillage agriculture. Soil Biol Biochem 32:20992103

Smith KA, Ball T, Conen F, Dobbie KE, Massheder J, Rey A (2003) Exchange of greenhouse gases between soil and atmosphere: interactions of soil physical factors and biological processes. Eur J Soil Sci 54:779-791. doi:10.1046/j.1365-2389.2003.00567.x

Smith P, Martin M, Cai Z, Gwary D, Janzen H, Kumar P, McCarl B, Ogle S, O'Mara F, Rice C, Scholes B, Sirotenko O, Howden M, McAllister T, Pan P, Romanenkov V, Schneider U, Towprayoon S, Wattenbach M, Smith J (2008) Greenhouse gas mitigation in agriculture. Philos T Roy Soc 363:789-813. doi:10.1098/ rstb.2007.2184

Soil Conservation Council of Canada (2003) Global warming in agriculture - best management practices. Agriculture and Agri-Food, Canada

Stavi I, Lal R (2011a) Loss of soil resources from water-eroded versus uneroded cropland sites under simulated rainfall. Soil Use Manage 27:69-76. doi:10.1111/j.1475-2743.2010.00312.x

Stavi I, Lal R (2011b) Variability of soil physical quality and erodibility in a water-eroded cropland. Catena 84:148-155. doi:10.1016/ j.catena.2010.10.006

Stavi I, Lal R, Owens LB (2011) On-farm effects of no-till versus occasional tillage on soil quality and crop yields in eastern Ohio. Agron Sustain Dev 31:475-482. doi:10.1007/s13593-011-0006-4

Stavi I, Lal R (2012) Agroforestry and biochar to offset climate change: a review. Agron Sustain Dev. doi:10.1007/s13593-012-0081-1. (in press)

Stehfest E, Bouwman L, van Vuuren DP, den Elzen MGJ, Eickhout B, Kabat P (2009) Climate benefits of changing diet. Clim Chang 95:83-102. doi:10.1007/s10584-008-9534-6

Tilman D, Fargione J, Wolff B, DÕAntonio C, Dobson A, Howarth R, Schindler D, Schlesinger WH, Simberloff D, Swackhamer D (2001) Forecasting agriculturally driven global environmental change. Science 292:281-284. doi:10.1126/science.1057544

Tilman D, Hill J, Lehman C (2006) Carbon-negative biofuels from low-input high-diversity grassland biomass. Science 314:15981600. doi: $10.1126 /$ science. 1133306

Tilman D, Socolow R, Foley JA, Hill J, Larson E, Lynd L, Pacala S, Reilly J, Searchinger T, Somerville C, Williams R (2009) Beneficial biofuels - the food, energy, and environment trilemma. Science 325:270-271. doi:10.1126/science. 1177970 
Thornton PK, van de Steeg J, Notenbaert A, Herrero M (2009) The impacts of climate change on livestock and livestock systems in developing countries: a review of what we know and what we need to know. Agr Syst 101:113-127. doi:10.1016/j.agsy.2009.05.002

Thornton PK, Gerber PJ (2010) Climate change and the growth of the livestock sector in developing countries. Mitig Adapt Strateg Glob 15:169-184. doi:10.1007/s11027-009-9210-9

UN (2011) Seven billion and growing: the role of population policy in achieving sustainability. Department of Economic and Social Affairs, Population Division, technical paper no. 2011/3.

Vadez V, Berger JD, Warkentin T, Asseng S, Ratnakumar P, Rao KPC, Gaur PM, Munier-Jolain N, Larmure A, Voisin AS, Sharma HC, Pande S, Sharma M, Krishnamurthy L, Zaman MA (2012) Adaptation of grain legumes to climate change: a review. Agron Sustain Dev 32:31-44. doi:10.1007/s13593-011-0020-6
Van Oost K, Quine TA, Govers G, De Gryze S, Six J, Harden JW, Ritchie JC, McCarty GW, Heckrath G, Kosmas C, Giraldez JV, Marques da Silva JR, Merckx R (2007) The impact of agricultural soil erosion on the global carbon cycle. Science 318:626-629. doi:10.1126/science. 1145724

Vergé XPC, Dyer JA, Desjardins RL, Worth D (2008) Greenhouse gas emissions from the Canadian beef industry. Agr Syst 98:126-134. doi:10.1016/j.agsy.2008.05.003

WMO (2010) WMO Greenhouse Gas Bulletin. The state of greenhouse gases in the atmosphere based on global observations through 2009. World Meteorological Organization, Geneva

WMO (2011) Weather extremes in a changing climate: hindsight on foresight. World Meteorological Organization, Geneva

Ziesemer J (2007) Energy use in organic food systems. Food and Agriculture Organization of the United Nations, Rome 